\title{
Nutritional Status of Post-Acute Stroke Patients during Rehabilitation Phase in Hospital
}

(Status Pemakanan Pesakit Selepas Strok semasa Fasa Pemulihan di Hospital)

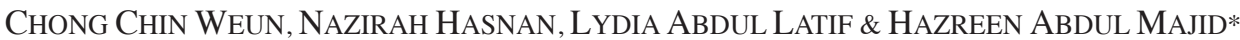

\begin{abstract}
Malnutrition is highly prevalent among stroke patients during post-acute rehabilitation phase and may give a negative effect on rehabilitation and impair recovery. However, to date, there is no reported study in Malaysia investigating the nutritional status of stroke patients during rehabilitation phase. Thus, this paper aims to report the preliminary results of nutritional assessment for a randomized controlled trial at baseline. All participating patients were assessed for anthropometric measurements, nutritional status using validated Mini Nutrition Assessment (MNA), 24 h diet recall, and handgrip strength. Demographic data, biochemical profiles and functional outcomes (Modified Barthel Index Score, Motor Assessment Scale) were obtained from patients' medical record. From a total of 45 post-acute stroke patients at baseline, $24.4 \%$ of them were malnourished during admission to rehabilitation ward and $66.7 \%$ of the patients were at risk of malnutrition. Mean dietary intake and protein intake of the patients were $1489 \pm 297 \mathrm{kcal} /$ day and $66.1 \pm 17.2 \mathrm{~g} /$ day, respectively. Mean handgrip strength for the patients was $17.9 \pm 8.1 \mathrm{~kg}$. Weight, body mass index, serum albumin, handgrip strength, Modified Barthel Index and Motor Assessment Scale score were positively correlated with MNA score $(\mathrm{p}<0.05)$, but no correlation was found for the dietary intake $(\mathrm{r}=0.163, \mathrm{p}=0.285)$ and protein intake $(\mathrm{r}=0.288, \mathrm{p}=0.055)$. This preliminary result showed that stroke patients are particularly at risk of malnutrition or malnourished during the rehabilitation period. Therefore, early identification of malnutrition for stroke patients is important for a successful rehabilitation program.
\end{abstract}

Keywords: Dietary intake; malnutrition; nutritional assessment

ABSTRAK

Malnutrisi adalah umum dalam kalangan pesakit strok semasa fasa pemulihan dan ini mungkin akan memberikan kesan negatifkepada proses pemulihan dan melambatkan proses penyembuhan. Walau bagaimanapun, tiada kajian di Malaysia yang menilai status pemakanan pesakit strok semasa fasa pemulihan. Kertas ini bertujuan untuk melaporkan keputusan penilaian pemakanan asas bagi satu kajian percubaan terkawal rawak (RCT). Semua pesakit yang terlibat dalam kajian tersebut telah dinilai dengan pengukuran antropometri, status pemakanan menggunakan Penilaian Pemakanan Mini (MNA), ingatan diet 24 jam dan kekuatan genggaman tangan. Data demografi, profil biokimia dan hasil ukuran kefungsian (Modified Barthel Index Score/MBI, Motor Assessment Scale/MAS) telah diperoleh daripada rekod perubatan pesakit. Daripada 45 orang pesakit selepas strok yang telah dinilai, $24.4 \%$ pesakit adalah malnutrisi manakala $66.7 \%$ pesakit adalah berisiko untuk mendapat malnutrisi. Purata pengambilan pemakanan dan pengambilan protein masing-masing adalah $1489 \pm 297 \mathrm{kkal} / \mathrm{hari}$ dan $66.1 \pm 17.2 \mathrm{~g} / \mathrm{hari}$. Purata kekuatan genggaman tangan adalah $17.9 \pm 8.1 \mathrm{~kg}$. Berat badan, indeks jisim tubuh, albumin darah, kekuatan tangan, MBI dan MAS menunjukkan hubungan kolerasi positf dengan skor MNA $(\mathrm{p}<0.05)$ manakala tiada kolerasi antara skor MNA dengan pengambilan pemakanan $(\mathrm{r}=0.163, \mathrm{p}=0.285)$ dan pengambilan protein $(\mathrm{r}=0.288, \mathrm{p}=0.055)$. Keputusan asas kajian ini menunjukkan pesakit strok adalah berisiko tinggi untuk mendapat malnutrisi semasa fasa pemulihan. Dengan sedemikian, pengesanan awal risiko malnutrisi adalah sangat penting dalam kalangan pesakit strok untuk proses pemulihan yang berkesan.

Kata kunci: Malnutrisi; penilaian pemakanan; pengambilan pemakanan

\section{INTRODUCTION}

Stroke contributes to major morbidity and mortality in both developed and developing countries, and in Malaysia, stroke is also one of the top five diseases with the greatest burden of disease (Aziz et al. 2014; Loo \& Gan 2012). Studies showed that stroke rehabilitation can improve functional ability even in patients who are elderly or medically ill and who have severe neurologic and functional deficits (Cifu \& Stewart 1999). However, even with optimal acute management and rehabilitation, there are some factors that may contribute to increased rehabilitation time and reduced functional outcomes in stroke patients, such as malnutrition and dysphagia (Crary et al.2006). Both malnutrition and dysphagia often coexist in stroke patients although the nature of their association remains poorly understood (Foley et al . 2009). Malnutrition 
may contribute to poor outcomes in stroke patients during both acute and rehabilitation phase (Bouziana \& Tziomalos 2011).

Malnutrition is highly prevalent among acute stroke patients upon admission and may worsen during hospitalization. Upon admission, the prevalence of malnutrition is estimated between $16 \%$ and $22 \%$ but increased to $22 \%$ and $26 \%$ through discharge from acute care. Malnutrition is more prevalent during the post-acute rehabilitation phase with a reported prevalence up to $50 \%$ (Finestone et al. 1995; Sura et al. 2012; van Zwienen-Pot et al. 2016). The presence of existing chronic diseases, swallowing difficulties and functional disabilities are associated with increased risk of malnutrition in stroke patients, particularly elderly individuals. In contrast, location and type of stroke, paresis of dominant arm, socioeconomic status and level of education were not significantly associated with malnutrition (Bouziana \& Tziomalos 2011). Malnutrition may develop as a consequence of poor monitoring of nutritional status, prolonged period of inadequate dietary intake during inpatient hospitalization and increased nutritional requirements during rehabilitation (Charlton et al. 2010; Foley et al. 2009).

Considering the consequences of malnutrition, it is most likely that poor nutritional status has a negative effect on the stroke rehabilitation and impairs recovery of stroke patients (van Zwienen-Pot et al. 2016). Early identification and management of malnutrition with proper dietary modifications or specific nutritional intervention are important during both acute and rehabilitation phase for stroke patients. The latest ESPEN (European Society of Clinical Nutrition and Metabolism) guideline for clinical nutrition in neurology suggests that all stroke patients should be screened for risk of malnutrition within $48 \mathrm{~h}$ on admission to hospital and patients who are malnourished or at risk of malnutrition should receive medical nutrition therapy through an individualized nutrition care plan (Burgos et al. 2018). To date, there are limited studies on nutritional assessment for stroke patients in Malaysia (Hamidon et al. 2006), particularly during post-acute rehabilitation phase and none of the studies investigates the effect of specific nutritional intervention on stroke patients. Therefore, we conducted a 3-month, single-blinded, randomized controlled trial to assess the nutritional status of post-acute stroke patients during admission to rehabilitation setting and particularly aims to evaluate the effects of intensive nutrition intervention on nutritional status and functional outcomes as compared to current practice. This paper will demonstrate the preliminary result of the baseline assessment for all recruited subjects prior to the nutritional intervention.

\section{MATERIALS AND METHODS}

This study was conducted in a tertiary referral hospital in central urban Malaysia. Ethical approval has been obtained from UMMC Medical Research Ethics Committee
(MRECID 201784-5471) and informed consent was obtained from all participants prior to data collection. Sample size was determined based on known population of average 60 patients in 6 months study period, it indicated that a minimum of 38 patients were required for $95 \%$ confidence interval and the precision of 0.10 (Naing et al.2006). Out of 167 patients who have been screened for eligibility, a total of 45 subjects were recruited between September 2017 and January 2018. Inclusion criteria were stroke patients who were admitted to rehabilitation ward for stroke rehabilitation purpose, no receptive/global aphasia or no communication barrier, no cognitive impairment and informed consent was obtained. Exclusion criteria were the patients aged below 40 years old, refused to participate, given full nasogastric $(\mathrm{NG})$ tube feeding or percutaneous endoscopic gastric (PEG) tube feeding, had dysphagia prior to stroke event, and with medical diseases/conditions which will restrict their nutritional intakes such as severe liver disease and fluid restriction.

After recruitment into the study, all participants were assessed and interviewed by a trained research dietitian using structured questionnaire. Demographic data and medical history were obtained from patient's record, which included age, date of birth, gender, education level, frequency of stroke, nature of stroke, side of stroke, comorbidities/risk factors, swallowing assessment and biochemical investigations such as serum albumin and total lymphocyte count. Swallowing ability or presence of dysphagia was determined by the Speech Therapist using Clinical Bedside Examination or Fiberoptic Endoscopic Examination of Swallowing (FEES).

Nutritional assessment was done by research dietitian using Mini Nutrition Assessment (MNA) and nutritional status of the subject was determined based on the result of MNA. The MNA is a validated nutrition assessment tool to provide a single, rapid assessment of nutritional status of frail older adults including stroke patients (Charlton et al. 2010; Guigoz et al. 1996; Suzana \& Siti Saifa 2007; Teasell et al. 2013; Vellas et al. 1999). The MNA consists of 18 questions, which included anthropometric measurements (weight, height, and weight loss), global assessment (six questions related to lifestyle, medication, and mobility), dietary questionnaire (eight questions, related to number of meals, food and fluid intake, and autonomy of feeding) and subjective assessment (self-perception of health and nutrition). The MNA score above 24 indicates the individual has normal nutritional status, score 17-23.5 shows at risk of malnutrition while a score below 17 indicates individual is malnourished. In this study, MNA score below 23.5 was used to indicate the patient has poor nutritional status. Weight was measured using SECA Electronic Wheelchair Scale Model 664 (SECA, Germany) to the nearest $0.1 \mathrm{~kg}$ while height was measured using SECA stadiometer Model 220 (SECA, Germany) or estimated using Knee Height Formula (Chumlea et al. 1985) for the individual who cannot stand straight.

Dietary intake was determined using $24 \mathrm{~h}$ diet recall where the patients and/or their caregiver were 
interviewed by research dietitian on consumption of food and beverages, starting from the time the patients woke up to the time they went to bed. One of the advantages of $24 \mathrm{~h}$ diet recall is subject could generally be able to recall most of their dietary intakes due to the immediacy of the recall period (Sun et al. 2010). The Food Atlas (Suzana et al. 2015) was used as a guide and reference during the interview session. Food intake was recorded in household measurements such as cups, bowls, teaspoons or tablespoons. Nutrient intake was analyzed using the Nutritionist Pro version 3.1.0 Software (AXXYA Systems US).

Information related to the functional outcomes of patients included Modified Barthel Index (MBI) score and Motor Assessment Scale (MAS) were obtained from patient's medical record and recorded as baseline data. The MBI score 0-20 indicates the individual has total dependency and score 21-60, 61-90, 91-99 and 100 shows individual are severe dependence, moderate dependence, minimal dependence and independence in activities of daily living respectively (Shah et al. 1989). The higher MAS score (0-54) shows the higher functioning of the patient on the affected side (Carr et al. 1985). Handgrip strength was measured using JAMAR hand dynamometer (Sammons Preston US), which study subjects will be asked to grip as firmly as possible using the unaffected hand. Sequential measurements were carried out 3 times to obtain the average value.

Data analysis was performed using Statistical Package for Social Study version 20.0 (SPSS Inc., Chicago, IL, USA). The variance statistics were used to describe continuous variables and prevalence statistics for categorical variables. Subject demographic variables were described by means and standard deviation or medians and interquartile range as indicated based on its normality. All data were assessed for normality using the Shapiro-Wilk test. Correlation analyses among outcome measures were used to determine whether these variables are associated with each other's by Pearson test or Spearman test. The statistical significance was reported at $p<0.05$.

\section{RESULTS AND DISCUSSION}

A total of 45 patients who met the inclusion criteria agreed to participate in the study (30 male and 15 female) with the mean age of $59.3 \pm 10.2$ years. The demographic and clinical characteristics of the 45 participants are shown in Table 1. Majority of the participants were having first stroke and diagnosed as ischemic stroke. Almost half of the patients had lesions in the right hemisphere, followed by another $44.4 \%$ of patients who were affected by left-sided stroke and $6.7 \%$ had bilateral body weakness. Majority of the patients also had hypertension $(91.1 \%)$, dyslipidemia $(60 \%)$ and diabetes mellitus (53.3\%). Swallowing assessment performed by Speech Therapists shows that 14 patients had dysphagia during admission where seven patients required diet modification to soft diet, five patients required pureed diet and two patients required modification to pureed texture. Most of the patients tolerated thin liquid consistency and only $6.7 \%$ required modification of liquid consistency. No significant differences were found in all baseline characteristics between male and female patients. Table 2 summarizes the nutritional and functional outcome measures of the patients during baseline assessment. Mean MNA score between male and female patients was similar $(19.1 \pm 4.2$ vs $18.7 \pm 3.3)$ where $23.3 \%$ of male patients and $26.7 \%$ of the female patients were malnourished based on MNA categories. In this study, the majority of the patients were at risk of malnutrition (66.7\%), which included $63.3 \%$ of the male patients and $73.3 \%$ of the female patients respectively. Mean body weight of male patients was significantly higher than female patients $(70.1 \pm 10.7 \mathrm{~kg}$ vs $60.4 \pm 9.3 \mathrm{~kg}, p<0.005)$. No significant differences were found for Body Mass Index, Mid Arm Circumference and Calf Circumference between male and female patients. Mean dietary intake of the male patients was slightly higher as compared to female patients, but the difference was not significant $(1520 \pm 294 \mathrm{kcal} /$ day vs $1426 \pm 303 \mathrm{kcal} /$ day, $p=0.319$ ). For mean protein intake, there was also no significant difference between male and female patients $(69.0 \pm 17.0 \mathrm{~g} /$ day vs $60.2 \pm 16.8 \mathrm{~g} / \mathrm{day}$, $p=0.110$ ). Similarly, handgrip strength for male patients was slightly higher as compared to female patients but the difference was not significant $(19.3 \pm 8.4 \mathrm{~kg}$ vs $15.0 \pm 6.8$ $\mathrm{kg}, p=0.094)$. As shown in Table 2, the MBI and MAS score between the two gender groups were also similar, where the result showed that majority of the patients had severe dependency during admission to the rehabilitation ward. This preliminary result demonstrated that $24.4 \%$ of postacute stroke patients were malnourished during admission to rehabilitation by using MNA categories. This finding was lower than the previously reported prevalence of 35-50\% (Finestone et al. 1995; Paquereau et al. 2014). However, our study showed that $66.7 \%$ of the patients were at risk of malnutrition, who also required further nutrition intervention to prevent malnutrition during intensive inpatient rehabilitation period (Burgos et al. 2018). The lower percentage of malnutrition in our study was attributed to the variation in nutritional assessment method and selection of study subjects. In this study, we only included the post-acute patients who received in-patient rehabilitation services and also excluded the patients on enteral tube feeding who were particularly at risk of malnutrition. Therefore, this may have contributed to the lower proportion of malnourished patients in this study. However, the body weight and BMI of the patients were similar to a previous observational study $(66.9 \mathrm{~kg}$, $24.9 \mathrm{~kg} / \mathrm{m}^{2}$ versus $70.0 \mathrm{~kg}, 24.5 \mathrm{~kg} / \mathrm{m}^{2}$ ) (Paquereau et al. 2014). This finding demonstrates that the stroke patients may still have normal BMI at post-acute rehabilitation period although they were already malnourished or at risk of malnutrition. This supports the previous finding that BMI is not a good indicator for malnutrition in hospitalized patients (Norman et al. 2008; Tsai et al. 2010).

In terms of nutritional intake, the present study shows that the post-acute stroke patients had a mean energy 
TABLE 1. Demographic and clinical characteristics of the participants at baseline

\begin{tabular}{|c|c|c|c|c|}
\hline & $\begin{array}{c}\text { All } \\
(n=45)\end{array}$ & $\begin{array}{l}\text { Male } \\
(n=30)\end{array}$ & $\begin{array}{l}\text { Female } \\
(n=15)\end{array}$ & $\mathrm{p}$ \\
\hline Age, years ${ }^{\mathrm{a}}$ & $59.3 \pm 10.2$ & $60.1 \pm 9.8$ & $57.9 \pm 11.3$ & 0.503 \\
\hline Frequency of stroke ${ }^{b}$ & & & & 0.502 \\
\hline First & $40(88.9)$ & $26(86.7)$ & $14(93.3)$ & \\
\hline Recurrent & $5(11.1)$ & $4(13.3)$ & $1(6.7)$ & \\
\hline Nature of stroke ${ }^{b}$ & & & & 0.110 \\
\hline Ischemic & $34(75.6)$ & $25(83.3)$ & $9(60.0)$ & \\
\hline Hemorrhagic & $10(22.2)$ & $4(13.3)$ & $6(40.0)$ & \\
\hline Combination & $1(2.2)$ & $1(3.3)$ & $0(0)$ & \\
\hline Side of stroke ${ }^{b}$ & & & & 0.054 \\
\hline Left & $20(44.4)$ & $16(53.3)$ & $4(26.7)$ & \\
\hline Right & $22(48.9)$ & $11(36.7)$ & $11(73.3)$ & \\
\hline Bilateral & $3(6.7)$ & $3(10.0)$ & $0(0)$ & \\
\hline \multicolumn{5}{|l|}{ Comorbidities/Risk factors ${ }^{\mathrm{b}}$} \\
\hline Hypertension & $41(91.1)$ & $27(90.0)$ & $14(93.3)$ & 0.711 \\
\hline Diabetes mellitus & $24(53.3)$ & $18(60.0)$ & $6(40.0)$ & 0.205 \\
\hline Atrial fibrillation & $2(4.4)$ & $1(3.3)$ & $1(6.7)$ & 0.609 \\
\hline Dyslipidemia & $27(60.0)$ & $17(56.7)$ & $10(66.7)$ & 0.519 \\
\hline Cardiac disorders & $6(13.3)$ & $5(16.7)$ & $1(6.7)$ & 0.352 \\
\hline Smoking & $5(11.1)$ & $5(16.7)$ & $0(0)$ & 0.094 \\
\hline Previous stroke & $5(11.1)$ & $4(13.3)$ & $1(6.7)$ & 0.502 \\
\hline Dysphagia $^{\mathrm{b}}$ & $14(31.1)$ & $10(33.3)$ & $4(26.7)$ & 0.649 \\
\hline Albumin, $g / L^{a}$ & $\begin{array}{c}35.5 \\
(32.0-39.0)\end{array}$ & $\begin{array}{c}35.0 \\
(32.0-40.0)\end{array}$ & $\begin{array}{c}35.5 \\
(32.0-38.8)\end{array}$ & 0.979 \\
\hline Total lymphocyte, $\times 10^{9} / \mathrm{L}^{\mathrm{c}}$ & $\begin{array}{c}1.88 \\
(1.49-2.61)\end{array}$ & $\begin{array}{c}1.75 \\
(1.49-2.25)\end{array}$ & $\begin{array}{c}2.61 \\
(1.56-3.08)\end{array}$ & 0.114 \\
\hline Type of diet texture ${ }^{b}$ & & & & 0.669 \\
\hline Regular texture & $31(68.9)$ & $20(66.7)$ & $11(73.3)$ & \\
\hline Soft & $7(15.6)$ & $6(20.0)$ & $1(6.7)$ & \\
\hline Minced and moist & $2(4.4)$ & $1(3.3)$ & $1(6.7)$ & \\
\hline Pureed/Blenderised & $5(11.1)$ & $3(10.0)$ & $2(13.3)$ & \\
\hline Type of liquid consistency ${ }^{b}$ & & & & 0.658 \\
\hline Thin liquid & $42(93.3)$ & $27(90.0)$ & $15(100.0)$ & \\
\hline Nectar consistency & $1(2.2)$ & $1(3.3)$ & $0(0)$ & \\
\hline Honey consistency & $1(2.2)$ & $1(3.3)$ & $0(0)$ & \\
\hline Spoon thick consistency & $1(2.2)$ & $1(3.3)$ & $0(0)$ & \\
\hline
\end{tabular}

${ }^{a}$ Mean $\pm \mathrm{SD}$ (Statistical significance will be detected using Student's $\mathrm{t}$ test at $p<0.05$.), ${ }^{\mathrm{b}}$ Number (\%) (Statistical significance will be detected using chi square test at $p<0.05$.), ${ }^{\mathrm{c}}$ Median (Interquartile Range) (Statistical significance will be detected using Mann-Whitney $\mathrm{U}$ Test at $p<0.05$.)

intake of $1489 \pm 297 \mathrm{kcal} / \mathrm{day}$ or $24.64 \pm 4.88 \mathrm{kcal} / \mathrm{kg} /$ day at admission to rehabilitation setting, which is also appeared to be lower than a previous study conducted in Japan (median $33.2 \mathrm{kcal} / \mathrm{kg} /$ day, IQR 29.2-39.75) (Nii et al. 2016). This result indicates our patients are particularly having inadequate dietary intake and hence require further nutritional intervention. On the other hand, we found that mean dietary and protein intake between patients without dysphagia and patients with modified texture diet were similar $(1511 \pm 277 \mathrm{kcal} /$ day, $65.2 \pm 17.6 \mathrm{~g}$ protein/day vs $1438 \pm 344 \mathrm{kcal} /$ day, $67.9 \pm 17.0 \mathrm{~g}$ protein/day). These findings are in contrast to the previous study where it found that older people on texture-modified diets have a lower intake of energy and protein than those consuming a normal hospital diet (3877kJ/day versus $6115 \mathrm{~kJ} /$ day) (Wright et al. 2005). This is probably due to the admitted patients who required modified texture diet would be given oral nutritional supplement in the current hospital to meet patient's dietary requirement. Stroke patients with oral supplementation would be having greater energy and protein intake as compared to non-supplemented patients (Gariballa et al. 1998). However, mean dietary intake of $24.64 \pm 4.88 \mathrm{kcal} / \mathrm{kg} /$ day demonstrates that patients were actually receiving inadequate energy intake prior to nutrition intervention with a median energy deficit of $413 \mathrm{kcal} / \mathrm{day}$ (range $227-557 \mathrm{kcal} /$ day). Patients received average protein intake of $1.10 \pm 0.27 \mathrm{~g} / \mathrm{kg} /$ day which achieve the minimal requirement of protein intake for stroke patients. 
TABLE 2. Nutritional-specific and functional outcome measures of the participants at baseline

\begin{tabular}{|c|c|c|c|c|}
\hline & $\begin{array}{c}\text { All } \\
(n=45)\end{array}$ & $\begin{array}{c}\text { Male } \\
(n=30)\end{array}$ & $\begin{array}{c}\text { Female } \\
(n=15)\end{array}$ & $\mathrm{p}$ \\
\hline MNA score ${ }^{a}$ & $19.0 \pm 3.9$ & $19.1 \pm 4.2$ & $18.7 \pm 3.3$ & 0.749 \\
\hline Nutritional status ${ }^{\mathrm{b}}$ & & & & 0.334 \\
\hline Malnourished & $11(24.4)$ & $7(23.3)$ & $4(26.7)$ & \\
\hline At risk of malnutrition & $30(66.7)$ & $19(63.3)$ & $11(73.3)$ & \\
\hline Good & $4(8.9)$ & $4(13.3)$ & $0(0)$ & \\
\hline Weight, $\mathrm{kg}^{\mathrm{a}}$ & $66.9 \pm 11.1$ & $70.1 \pm 10.7$ & $60.4 \pm 9.3$ & $0.005^{*}$ \\
\hline $\mathrm{BMI}, \mathrm{kg} / \mathrm{m}^{2 \mathrm{a}}$ & $24.9 \pm 3.2$ & $24.9 \pm 3.1$ & $24.9 \pm 3.6$ & 0.962 \\
\hline MAC, $\mathrm{cm}^{\mathrm{a}}$ & $28.4 \pm 3.0$ & $28.1 \pm 2.8$ & $29.1 \pm 3.4$ & 0.246 \\
\hline Calf circumference, $\mathrm{cm}^{\mathrm{c}}$ & $29.5(27.0-31.4)$ & $29.5(27.0-31.1)$ & $30.0(28.0-31.5)$ & 0.454 \\
\hline Dietary intake, $\mathrm{kcal} / \mathrm{day}^{\mathrm{a}}$ & $1489 \pm 297$ & $1520 \pm 294$ & $1426 \pm 303$ & 0.319 \\
\hline Energy intake, $\mathrm{kcal} / \mathrm{kg} /$ day $^{\mathrm{a}}$ & $24.64 \pm 4.88$ & $23.87 \pm 4.67$ & $24.64 \pm 4.88$ & 0.132 \\
\hline Energy deficit, kcal/day ${ }^{\mathrm{c}}$ & $413(227-557)$ & $436(228-620)$ & $324(176-455)$ & 0.267 \\
\hline Protein intake, $\mathrm{g} /$ day $^{\mathrm{a}}$ & $66.1 \pm 17.2$ & $69.0 \pm 17.0$ & $60.2 \pm 16.8$ & 0.110 \\
\hline Protein intake, $\mathrm{g} / \mathrm{kg} / \mathrm{day}^{\mathrm{a}}$ & $1.10 \pm 0.27$ & $1.09 \pm 0.25$ & $1.11 \pm 0.31$ & 0.820 \\
\hline Handgrip strength, $\mathrm{kg}^{\mathrm{a}}$ & $17.9 \pm 8.1$ & $19.3 \pm 8.4$ & $15.0 \pm 6.8$ & 0.094 \\
\hline MBI score ${ }^{a}$ & $53.2 \pm 18.7$ & $52.3 \pm 19.3$ & $54.9 \pm 17.9$ & 0.665 \\
\hline MAS score ${ }^{c}$ & $21(16-37.25)$ & $22(18-41)$ & $18(14-36)$ & 0.167 \\
\hline
\end{tabular}

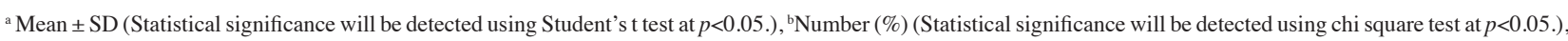
${ }^{\mathrm{c}}$ Median (Interquartile Range) (Statistical significance will be detected using Mann-Whitney U Test at $p<0.05$.)

In the present study, weight, BMI, serum albumin, handgrip strength, MBI and MAS score were positively correlated with MNA score but the dietary intake and protein intake were not (Table 3). This is similar to previous studies which shows that patients with greater weight and BMI will tend to have better nutritional status but current dietary and protein intake are not correlated with present nutritional status (Paquereau et al. 2014). Handgrip strength and MBI/ MAS were also significantly influenced by nutritional status. Stroke patients with good nutritional status are those with greater handgrip strength and better MNA or MAS score. Previous studies reported that hand strength reflects hand function (Heller et al. 1987; Kim 2016). Sunderland et al. (1989) suggested that hand strength is a critical indicator of functional recovery in stroke in which hand strength improves in proportion to the complicated motor task ability of the upper extremities. Therefore, patients with good nutritional status will have greater handgrip strength and thus may have a better extent of recovery throughout rehabilitation period.

Good nutritional status is more likely to contribute to the successful rehabilitation of patients (Ha et al. 2010; van Zwienen-Pot et al.2016); however, the baseline nutritional assessment in this study demonstrates that majority of the stroke patients were at risk of malnutrition and did not receive sufficient energy intake at admission. This present study supports previous findings indicating that dietary inadequacy is common after stroke, with suboptimal energy intake being more prevalent than insufficient protein intake (Nip et al. 2011; Perry \& McLaren 2004). A previous study which recorded all patients' food intake indicated that many patients did not consume all food provided by hospital, with up to $25 \%$ of food being wasted and may be substituted by the consumption of non-hospital food, either bought from shops or brought in by family members (Nip et al. 2011). Nevertheless, an individualized nutritional treatment plan

TABLE 3. Correlation of MNA score with anthropometric, biochemical, nutritional and functional outcome parameters

\begin{tabular}{lcc}
\hline Parameters & $\mathrm{r}$ & $\mathrm{p}$-value \\
\hline Weight at baseline & 0.397 & $0.007^{*}$ \\
BMI & 0.459 & $0.002^{*}$ \\
Serum albumin & 0.441 & $0.003^{*}$ \\
Total lymphocyte & 0.099 & 0.549 \\
Dietary intake & 0.163 & 0.285 \\
Protein intake & 0.288 & 0.055 \\
Handgrip strength & 0.526 & $0.000^{*}$ \\
MBI score & 0.527 & $0.000^{*}$ \\
MAS score & 0.476 & $0.007^{*}$ \\
\hline
\end{tabular}

${ }^{*} p<0.05$, significant correlation between MNA score and other parameters by Pearson correlation, $* * p<0.05$, significant correlation between MNA score and MAS score by Spearman correlation 
TABLE 4. Dietary intake, protein intake and functional outcome measures of the participants by swallowing ability

\begin{tabular}{|c|c|c|c|}
\hline & $\begin{array}{l}\text { Dysphagia } \\
(n=14)\end{array}$ & $\begin{array}{l}\text { Non-dysphagia } \\
\quad(n=31)\end{array}$ & $\mathrm{p}$ \\
\hline Dietary intake, $\mathrm{kcal} /$ day $^{\mathrm{a}}$ & $1438 \pm 344$ & $1511 \pm 277$ & 0.452 \\
\hline Protein intake, $g /$ day $^{\mathrm{a}}$ & $67.9 \pm 17.0$ & $65.2 \pm 17.6$ & 0.634 \\
\hline Handgrip strength, $\mathrm{kg}^{\mathrm{a}}$ & $15.2 \pm 6.8$ & $19.1 \pm 8.5$ & 0.144 \\
\hline MBI score ${ }^{\mathrm{b}}$ & $36(32-53.3)$ & $52(46-68)$ & $0.004 *$ \\
\hline MAS score ${ }^{b}$ & $21(9-41)$ & $21(16.5-36)$ & 0.755 \\
\hline
\end{tabular}

a Mean \pm SD (Statistical significance will be detected using Student's t test at $p<0.05$.)

${ }^{\mathrm{b}}$ Median (Interquartile Range) (Statistical significance will be detected using Mann-Whitney U Test at $p<0.05$.)

tailored to the specific needs of the patient with regular monitoring, can help to meet dietary requirements and prevent further weight loss, and can also contribute to the improvement of functional status and quality of life among stroke patients (Burgos et al. 2018).

Data on nutritional status for stroke patients in local setting is scarce, particularly during post-acute rehabilitation phase. For this reason, the strength of this study lies in its unique study population. However, our study had some limitations. The sample size was relatively small and we only included a subgroup of patients admitted to rehabilitation ward for intensive rehabilitation but excluded the patients who were not suitable for intensive inpatient rehabilitation and stayed in neurology or stroke ward for a longer period. This may have contributed to lower percentage of malnourished patients due to the patients with more severe impairments and those who were given tube feeding with poor nutritional status were excluded. However, this baseline result is part of a randomized intervention study particularly aims to examine the effects of individualized nutritional intervention as compared to current practice. Although this may have limited the generalizability of other post-acute stroke patients who did not undergo in-patient rehabilitation services, the findings of the study do support previous research that malnutrition is prevalent during post-acute phase and dietary inadequacy is common among the stroke patients. Dietary information obtained from $24 \mathrm{~h}$ diet recall has a limited ability to capture day-to-day variation in eating, although variation may be small within an institutionalized setting. Furthermore, even though the current study had a small sample size and was conducted in a single study center, the comprehensive nutritional assessment findings can provide valuable local data on post-acute stroke patients and thus to highlight the importance of early nutrition assessment and appropriate nutrition intervention as part of comprehensive rehabilitation therapy.

\section{CONCLUSION}

Stroke patients are particularly at risk of malnutrition or malnourished during the rehabilitation period. Currently, there is scarce information regarding nutritional status and dietary intake among stroke patients particularly at the post-acute level and follow up in the community, therefore, this preliminary result emphasizes the importance of comprehensive nutritional assessment for stroke patients so that appropriate nutritional intervention plan can be implemented to prevent the deterioration of nutritional status of post-acute stroke patients. Effective nutritional intervention leads to the improvement of functional status and therefore can contribute to the successful rehabilitation program.

\section{ACKNOWLEDGEMENTS}

We would like to thank all participating patients for their patience and cooperation and the staffs from Rehabilitation Ward, Department of Dietetics and Department of Rehabilitation Medicine, University of Malaya Medical Centre for their support and assistance towards the study.

\section{REFERENCES}

Aziz, A.F.A., Nordin, N.A.M., Aziz, N.A., Abdullah, S., Sulong, S. \& Aljunid, S.M. 2014. Care for post-stroke patients at Malaysian public health centres: Self-reported practices of family medicine specialists. BMC Family Practice 15(1): 1.

Bouziana, S.D. \& Tziomalos, K. 2011. Malnutrition in patients with acute stroke. Journal of Nutrition and Metabolism 2011: 167898.

Burgos, R., Bretón, I., Cereda, E., Desport, J.C., Dziewas, R., Genton, L., Gomes, F., Jésus, P., Leischker, A., Muscaritoli, M., Poulia, K.A., Preiser, J.C., Van der Marck, M., Wirth, R., Singer, P. \& Bischoff, S.C. 2018. ESPEN guideline clinical nutrition in neurology. Clinical Nutrition 37(1): 354-396.

Carr, J.H., Shepherd, R.B., Nordholm, L. \& Lynne, D. 1985. Investigation of a new motor assessment scale for stroke patients. Phys. Ther. 65(2): 175-180.

Charlton, K.E., Nichols, C., Bowden, S., Lambert, K., Barone, L., Mason, M. \& Milosavljevic, M. 2010. Older rehabilitation patients are at high risk of malnutrition: Evidence from a large Australian database. The Journal of Nutrition, Health \& Aging 14(8): 622-628.

Chumlea, W.C., Roche, A.F. \& Steinbaugh, M.L. 1985. Estimating stature from knee height for persons 60 to 90 years of age. J. Am. Geriatr. Soc. 33(2): 116-120.

Cifu, D.X. \& Stewart, D.G. 1999. Factors affecting functional outcome after stroke: A critical review of rehabilitation interventions. Archives of Physical Medicine and Rehabilitation 80(5): S35-S39.

Crary, M.A., Carnaby-Mann, G.D., Miller, L., Antonios, N. \& Silliman, S. 2006. Dysphagia and nutritional status at the time 
of hospital admission for ischemic stroke. Journal of Stroke and Cerebrovascular Diseases 15(4): 164-171.

Finestone, H.M., Greene-Finestone, L.S., Wilson, E.S. \& Teasell, R.W. 1995. Malnutrition in stroke patients on the rehabilitation service and at follow-up: Prevalence and predictors. Archives of Physical Medicine and Rehabilitation 76(4): 310-316.

Foley, N.C., Martin, R.E., Salter, K.L. \& Teasell, R.W. 2009. A review of the relationship between dysphagia and malnutrition following stroke. Journal of Rehabilitation Medicine 41(9): 707-713.

Gariballa, S.E., Parker, S.G., Taub, N. \& Castleden, C.M. 1998. A randomized, controlled, single-blind trial of nutritional supplementation after acute stroke. Journal of Parenteral and Enteral Nutrition 22(5): 315-319.

Guigoz, Y., Vellas, B. \& Garry, P.J. 1996. Assessing the nutritional status of the elderly: The Mini Nutritional Assessment as part of the geriatric evaluation. Nutr. Rev. 54(1 Pt 2): S59-S65.

Ha, L., Hauge, T. \& Iversen, P.O. 2010. Body composition in older acute stroke patients after treatment with individualized, nutritional supplementation while in hospital. BMC Geriatr. 10: 75 .

Hamidon, B.B., Abdullah, S.A., Zawawi, M.F., Sukumar, N., Aminuddin, A. \& Raymond, A.A. 2006. A prospective comparison of percutaneous endoscopic gastrostomy and nasogastric tube feeding in patients with acute dysphagic stroke. Med. J. Malaysia 61(1): 59-66.

Heller, A., Wade, D.T., Wood, V.A., Sunderland, A., Hewer, R.L. \& Ward, E. 1987. Arm function after stroke: Measurement and recovery over the first three months. J. Neurol. Neurosurg. Psychiatry 50(6): 714-719.

Kim, D. 2016. The effects of hand strength on upper extremity function and activities of daily living in stroke patients, with a focus on right hemiplegia. Journal of Physical Therapy Science 28(9): 2565-2567.

Loo, K.W. \& Gan, S.H. 2012. Burden of stroke in Malaysia. International Journal of Stroke 7(2): 165-167.

Naing, L., Winn, T. \& Rusli, B. 2006. Sample Size Calculator for Prevalence Studies. Version 1.0.01. http://www.kck.usm. $\mathrm{my} / \mathrm{ppsg} / \mathrm{stats}$ resources.htm.

Nii, M., Maeda, K., Wakabayashi, H., Nishioka, S. \& Tanaka, A.2016. Nutritional improvement and energy intake are associated with functional recovery in patients after cerebrovascular disorders. Journal of Stroke and Cerebrovascular Diseases 25(1): 57-62.

Nip, W., Perry, L., McLaren, S. \& Mackenzie, A. 2011. Dietary intake, nutritional status and rehabilitation outcomes of stroke patients in hospital. Journal of Human Nutrition and Dietetics 24(5): 460-469.

Norman, K., Pichard, C., Lochs, H. \& Pirlich, M. 2008. Prognostic impact of disease-related malnutrition. Clinical Nutrition 27(1): 5-15.

Paquereau, J., Allart, E., Romon, M. \& Rousseaux, M. 2014. The long-term nutritional status in stroke patients and its predictive factors. Journal of Stroke and Cerebrovascular Diseases 23(6): 1628-1633.

Perry, L. \& McLaren, S. 2004. An exploration of nutrition and eating disabilities in relation to quality of life at 6 months post-stroke. Health \& Social Care in the Community 12(4): 288-297.
Shah, S., Vanclay, F. \& Cooper, B. 1989. Improving the sensitivity of the Barthel Index for stroke rehabilitation. Journal of Clinical Epidemiology 42(8): 703-709.

Sun, Y., Roth, D.L., Ritchie, C.S., Burgio, K.L. \& Locher, J.L. 2010. Reliability and predictive validity of energy intake measures from the 24-hour dietary recalls of homebound older adults. Journal of the American Dietetic Association 110(5): 773-778.

Sunderland, A., Tinson, D., Bradley, L. \& Hewer, R.L. 1989. Arm function after stroke. An evaluation of grip strength as a measure of recovery and a prognostic indicator. Journal of Neurology, Neurosurgery \& Psychiatry 52(11): 1267-1272.

Sura, L., Madhavan, A., Carnaby, G. \& Crary, M.A. 2012. Dysphagia in the elderly: Management and nutritional considerations. Clin. Interv. Aging 7(7): 287-298.

Suzana, S. \& Siti Saifa, H. 2007. Validation of nutritional screening tools against anthropometric and functional assessments among elderly people in Selangor. Malays $J$. Nutr. 13(1): 29-44.

Suzana, S., Nik Shanita, S., Zahara, A.M. \& Hasnah, H. 2015. Atlas Makanan: Saiz Pertukaran dan Porsi. 3rd ed.

Teasell, R., Foley, N., Richardson, M., Bhogal, S. \& Speechley, M. 2013. Nutritional Interventions Following Stroke. http:// ebrsr.com/evidence-review/16-nutritional-interventionsfollowing-stroke.

Tsai, A.C., Chang, T.L., Wang, Y.C. \& Liao, C.Y. 2010. Population-specific short-form mini nutritional assessment with body mass index or calf circumference can predict risk of malnutrition in community-living or institutionalized elderly people in Taiwan. J. Am. Diet Assoc. 110(9): 1328-1334.

van Zwienen-Pot, J., Visser, M., Kuijpers, M., Grimmerink, M. \& Kruizenga, H. 2016. Undernutrition in nursing home rehabilitation patients. Clinical Nutrition 2016: 1-5.

Vellas, B., Guigoz, Y., Garry, P.J., Nourhashemi, F., Bennahum, D., Lauque, S. \& Albarede, J.L. 1999. The Mini Nutritional Assessment (MNA) and its use in grading the nutritional state of elderly patients. Nutrition 15(2): 116-22.

Wright, L., Cotter, D., Hickson, M. \& Frost, G. 2005. Comparison of energy and protein intakes of older people consuming a texture modified diet with a normal hospital diet. Journal of Human Nutrition and Dietetics 18(3): 213-219.

Chong Chin Weun \& Hazreen Abdul Majid*

Department of Social and Preventive Medicine

Faculty of Medicine, University of Malaya

50603 Kuala Lumpur, Federal Territory

Malaysia

Nazirah Hasnan \& Lydia Abdul Latif

Department of Rehabilitation Medicine

Faculty of Medicine, University of Malaya

50603 Kuala Lumpur, Federal Territory

Malaysia

*Corresponding author; email: hazreen@ummc.edu.my

Received: 2 May 2018

Accepted: 30 August 2018 